\title{
THE IMPLEMENTATION OF QUALITY PRESCRIPTION SERVICE AT HOSPITAL, PANGKALPINANG, BANGKA BELITUNG
}

\author{
Rachmawati Felani Djuria
}

\author{
School of Health Polytechnics, Ministry of Health Pangkalpinang
}

\begin{abstract}
Background: Prescription communicates medication plans from prescribers to pharmacists and patients. An error prescribed will often not be checked until a pharmacist reviews the patient's prescription, which may not happen for up to 72 hours after admission. There is a need for hospitals to give the best of the prescription assessment and services. This study aimed to analyze the implementation of quality prescription assessment and services at a hospital in Pangkalpinang, Bangka Belitung.

Subjects and Method: This was a qualitative study conducted at a Pangkalpinang hospital, Bangka Belitung, from February to December 2017. The quality control was conducted by audit. The key informants were selected by triangulation. The dependent variables were prescription review and service. The independent variables were administrative requirement, pharmaceutical requirement, clinical requirement, acceptance, availability check, pharmaceutical preparation, medical device, and disposable material. The data were analyzed descriptively.

Results: Prescription service had been implemented sub-optimally. This service did not adhere the pharmaceutical service standard for hospital set by the Ministry of Health. The prescription service was delivered by nurses. Some inpatients did not receive prescription services. Pharmacists were unrecognized by patients.

Conclusion: Prescription service has been implemented sub-optimally. This service do not adhere the pharmaceutical service standard for hospital set by the Ministry of Health.
\end{abstract}

Keywords: pharmaceutical service standard, prescription, pharmacists

\section{Correspondence:}

Rachmawati Felani Djuria. School of Health Polytechnic, Ministry of Health Pangkalpinang, Bangka Belitung. Email: felanDJ87@gmail.com. Mobile: o81995596959.

The $6^{\text {th }}$ International Conference on Public Health

Best Western Premier Hotel, Solo, Indonesia, October 23-24, 2019 | 243

https://doi.org/10.26911/the6thicph.04.05 